\title{
Review
}

\section{Human rights and the care of the self}

\author{
Alexandre Lefebvre \\ Durham, Duke University Press, 2018, x + 249 pp., \\ ISBN: 978-0-8223-7131-1
}

Contemporary Political Theory (2019) 18, S42-S44. https://doi.org/10.1057/s41296018-00292-x; published online 3 December 2018

In this intriguing and endlessly interesting new book, the Australian-based philosopher and political theorist, Alexandre Lefebvre, who has written extensively on Henri Bergson, Gilles Deleuze and Baruch Spinoza, turns his formidable attention to Michel Foucault and human rights. As readers in both these fields of study will appreciate, the bar is now set very high for originality and newness. Foucault has been dead for several decades but (courtesy, in part, of the continuing posthumous publication of his annual lecture courses at the Collège de France) exegeses and applications of his work continue to proliferate around the world in many languages. The same, of course, could be said for human rights (even in an age like the present where, according to many commentators, they are imperiled by populism, neoliberalism, authoritarianism, and so forth). How to overcome 'Foucault fatigue'? What is there left to say about human rights that has not been said before? Each of these tests is stern enough, intellectually, on their own; Lefebvre sets himself the task of satisfying them both in a single concise book and he does so with verve, style, humour and insight.

Human rights and the care of the self makes a dual intervention. Let me take the Foucauldian intervention first. Magritte-like, Lefebvre opens his account by insisting 'that this is not a book on Foucault' (p. 10). Of course, this is true in the sense that Human rights and the care of the self does not devote itself exegetically to parsing Foucault's texts but rather deftly uses a particular concept in Foucault's late work, the care of the self, to examine a range of human rights thinkers (in turn, Mary Wollstonecraft, Alexis de Tocqueville, Bergson, and Charles Malik) and a set of contemporary human rights practices (human rights education). And yet this is plainly a book on and about Foucault. In deploying Foucault's late body of work on ethics and on the care of the self to make an argument about human rights, Lefebvre mounts a gentle argument with Foucault himself about the persistence of the care of the self into modernity and into the juridical realm and also provides a fresh and provocative take on a well-worn topic in the secondary literature on

(c) 2018 Springer Nature Limited. 1470-8914 Contemporary Political Theory Vol. 18, S1, S42-S44 
Foucault (namely, the political status of the late work on ethics, and whether Foucauldian ethics constitute a solipsistic withdrawal from political action).

For the scholar of Foucault, there is much to appreciate in this excellent book, and while I just described Lefebvre's intervention into this field as 'provocative', I suspect that adjective better describes Lefebvre's reframing of human rights discourse and practice. To many human rights scholars and practitioners (and definitely to the waves of idealistic law students - many of whom I teach in my law school, year-after-year - who are drawn to international human rights law so as to 'change the world' or, less hubristically, perhaps, to 'make a difference') it is almost axiomatic that the purpose of human rights is to improve the lives of people (usually other people, in far-flung war-torn places). Human rights and the care of the self playfully contests this axiom. For Lefebvre, far from being about improving the lot of others in life, human rights are best understood 'as a tool for selftransformation and self-improvement for the sake of oneself' (p. 9). In brief, and using Foucault's notion of the care of the self as his guide, Lefebvre proposes that human rights be seen as a form of personal transformation and self-improvement that is undertaken voluntarily and not for any social or wider purpose.

Acknowledging that this 'may seem indulgent or just plain immoral', and that this interpretation 'appears to funnel a leading institution for global justice into yet another kind of self-help for the already privileged' (p. 3), Lefebvre nevertheless unfolds this unorthodox (yet intriguing) reading of human rights across chapters devoted to the writings of (primarily) philosophers who, each in their different way, emphasize the importance of human rights as a way of life undertaken to improve the self. The series of author studies that Lefebvre curates do not amount to a fully fledged 'tradition', as his characters are not in explicit dialogue with each other, and, in any event, they each understand the care of the self in a slightly different and historically situated way (for the eighteenth-century Wollstonecraft, whom we encounter in Chapter 2, human rights help the individual to contest chivalry, whereas for the twentieth-century Malik, the subject of Chapter 8, they 'promise...spiritual redemption' (p. 155)). In Chapter 4, Lefebvre reads Tocqueville with the French philosopher and historian of ancient philosophy, Pierre Hadot (a great influence on Foucault's own late work on ethics), in order to show how, for the former, exercising universal civil and political rights in a democratic context is a means both for self-transformation and for becoming-democratic. As Lefebvre puts it nicely: 'it is through the practice of political rights that citizens in democracy will be able to counteract the spiritual afflictions of democracy [tyranny and debasement, for example]) (p. 63, emphasis in original). The French philosopher Bergson (impressively well-trodden territory for Lefebvre, the subject of his 2013 book, Human rights as a way of life) features in Chapter 5 as a proponent of human rights providing a medium for the individual practitioner to attain to what he calls 'open love' (p. 96). In contrast, for Eleanor Roosevelt, the focus of Chapter 7, practicing human rights as a care of the self allows the 
individual to overcome fear and conformity and to assert their individuality in an age (for her) of pernicious collectivism. It is clear from such a brief survey that Lefebvre's intellectual resources each perceive a different role for human rights, but, regardless, the sum of Lefebvre's impressive re-reading of these human rights thinkers is to make us pause and rethink both the history and the possible future trajectory of human rights.

Unsurprisingly for a Foucauldian text (indeed, to be honest, for any text this rich with insight) there are multiple possible readings and directions in which to take Lefebvre's analysis. This reader, perhaps more critical of the contemporary human rights enterprise than the author of the work under review (whose text is avowedly written on behalf of, rather than as a critique of, human rights) finds much to work with in terms of generating a critique of the kinds of political subjectivities and ethical sensibilities produced by mainstream human rights discourse. But, regardless of the various political uses to which this excellent book will give rise (in the university classroom or indeed, perhaps as a manual for the contemporary spiritual exercise of human rights, in everyday life or in the human rights movement!), it is clear that Human rights and the care of the self is a beautifully written, erudite and teacherly (in the best sense - not dry and didactic but gently thought-provoking) account of a range of thinkers and a powerful re-reading of the concept of human rights itself.

Ben Golder

University of New South Wales, Sydney, NSW 2052, Australia

b.golder@unsw.edu.au 